\title{
KRONIKA
}

\section{MIĘDZYNARODOWA INTERDYSCYPLINARNA SESJA STUDENTÓW ARCHEOLOGII: „DŹWIĘKI KULTURY. MUZYKA JAKO KOMUNIKAT W PRZESZŁOŚCI" (PUSZCZYKOWO, 18-20 GRUDNIA 2006 R.)}

W dniach 18-20 XII 2006 r. odbyła się VIII Międzynarodowa Interdyscyplinarna Sesja Studentów Archeologii zatytułowana: „Dźwięki kultury. Muzyka jako komunikat w przeszłości". Jej pomysłodawcami i organizatorami byli studenci zrzeszeni w Kole Naukowym Studentów Archeologii (KNSA) przy Instytucie Prahistorii Uniwersytetu im. Adama Mickiewicza w Poznaniu. Ze względu na remont Domu Pracy Twórczej i Wypoczynku UAM w Obrzycku, w którym zorganizowaliśmy siedem poprzednich spotkań, odbyła się ona w Leśnym Ośrodku Szkoleniowym w Puszczykowie. Wsparcia finansowego udzielił nam Rektor UAM oraz Dziekan Wydziału Historycznego, jak również Instytut Prahistorii i Fundacja UAM. Patronat honorowy nad konferencją objęli Jego Magnificencja Rektor UAM oraz Wojewoda Wielkopolski. Za organizację przedsięwzięcia odpowiedzialni byli studenci z KNSA: Mariusz Drzewiecki, Piotr Niemiec-Miśkiewicz oraz Maksymilian Frąckowiak.

Do Puszczykowa przyjechało 60 uczestników pochodzących z różnych ośrodków akademickich z kraju i zagranicy, reprezentujących kierunki humanistyczne, takie jak: archeologia, historia, historia sztuki, muzykologia, kulturoznawstwo, etnologia, polonistyka i psychologia. Gośćmi z zagranicy byli studenci z Uniwersytetu w Zagrzebiu. Sesję otworzył prezes KNSA Maksymilian Frąckowiak i równocześnie ogłosił inaugurację Roku Jubileuszowego, z okazji 80. rocznicy powstania poznańskiego Koła Naukowego Studentów Archeologii. Następnie głos zabrała Dziekan Wydziału Historycznego prof. dr hab. Danuta Minta-Tworzowska. Na ceremonii otwarcia obecny był również Prodziekan Wydziału Historycznego prof. dr hab. Zbigniew Pilarczyk oraz przedstawiciele kadry Instytutu Prahistorii. Kolejnym punktem programu był referat wprowadzający Barbary Subotkowskiej pt. „Muzykoterapia pradziejowa”, w którym autorka ukazała wielowymiarowy charakter muzyki oraz jej wpływ na ciało i umysł człowieka w różnych społeczeństwach i epokach. Następnie odbyły się warsztaty wprowadzające 
pt. „Klucz do świata dźwięków” przygotowane przez Kingę Vorbrich. W warsztatach udział wzięli także zaproszeni goście. Odbywały się one w siedmiu zamkniętych grupach, kierowanych przez Tomasza Michalika, Martę Kalisz, Piotra Niemca-Miśkiewicza, Joannę Grabowską, Maksymiliana Frąckowiaka, Olgę Tarczyńską oraz Natalię Racek. Warsztaty miały na celu stworzenie forum do dyskusji nad różnymi obliczami dźwięków, ich odmienną proweniencją, znaczeniem oraz oddziaływaniem na człowieka. Efekty tych rozważań zostały następnie zaprezentowane wszystkim uczestnikom w postaci graficznych obrazów, omawianych przez przedstawicieli poszczególnych grup. Kulturalnym zwieńczeniem pierwszego dnia konferencji był koncert zespołu „Kapela Hałasów”, wykonującego dawną muzykę ludową na tradycyjnych instrumentach, pochodzącą z różnych krajów słowiańskich, po którym odbył się wieczorek towarzyski.

W trakcie drugiego dnia obrad odbyły się dwie sesje tematyczne. Sesję I, której tematem przewodnim była „Muzyka w świecie religii”, otworzył referat Michała Majchrzyckiego pt. „Muzyka jako kerygmat. Wykorzystanie współczesnej kultury w ewangelizacji”. Jego celem było pokazanie wpływu muzyki rockowej na ewangelizację młodzieży oraz ukazanie pomostu między muzyką a doświadczeniem sacrum i wiary. Następnie Mariusz Drzewiecki w wystąpieniu zatytułowanym „Muzyka Makurii” przedstawił dostępne materiały źródłowe i ich możliwości interpretacyjne odnoszące się do muzyki i tańca w średniowiecznym królestwie, leżącym na terenie dzisiejszego północnego Sudanu. Sesję II pt. „Muzyka a odbiór świata” rozpoczął Leszek Gardeła. Zagadnienia, jakie poruszył w swoim referacie pt. „Słowa, które wiążą wiatr. Rytualne platformy i rola śpiewu w praktyce seiðr", dotyczyły wpływu śpiewu na siłę ekspresji i sugestii w obrzędowości epoki wikingów. Kolejnym prelegentem był Marcin Jauksz, który w referacie „Słyszeć pismem. Rzecz o Don Giovannim Sørena Kierkegaarda” mówił o szczególnej roli muzyki w filozofii egzystencjalistycznej duńskiego poety i filozofa doby romantyzmu. Następnie wystąpił Mateusz Karolak. Jego rozważania zatytułowane „Wpływ muzyki na wychowanie w klasycznej Grecji” miały za cel ukazanie wyjątkowej roli tej sztuki w wychowaniu młodego człowieka według koncepcji Platona. Sesję II zakończył referat pt. „Instrumenty muzyczne w micie”, w którym Łukasz Pospieszny opowiadał o symbolicznym znaczeniu tych przedmiotów w kulturze greckiej. Na zakończenie drugiego dnia odbyło się ognisko, na którym wielu uczestników konferencji prezentowało swoje muzyczne umiejętności.

Trzeci dzień obrad otworzyła Daria Dąbal. Treścią wystąpienia pt. „Miejsca, gdzie można «usłyszeć» przeszłość” były motywy dźwiękowe towarzyszące ekspozycjom w rezerwatach archeologicznych i muzeach na wolnym powietrzu, które dzięki swej sile perswazji mają pomóc widzowi w doświadczaniu przeszłej rzeczywistości. Następnie odbyła się dyskusja podsumowująca trzy konferencyjne dni, poprowadzona przez prof. dr. hab. Włodzimierza Rączkowskiego. Był to czas na pytania do referentów oraz okazja do wymiany poglądów i stworzenia platformy dyskusji na temat muzyki między przedstawicielami różnych humanistycznych dyscyplin. Rozważania studentów krążyły wokół tematu wewnątrzkulturowej i międzykulturowej komunikacyjnej roli muzyki, jak również 


\section{DŹWIĘKI KULTURY}

MUZYKA JAKO KOMUNIKAT W PRZESZŁOŚCI

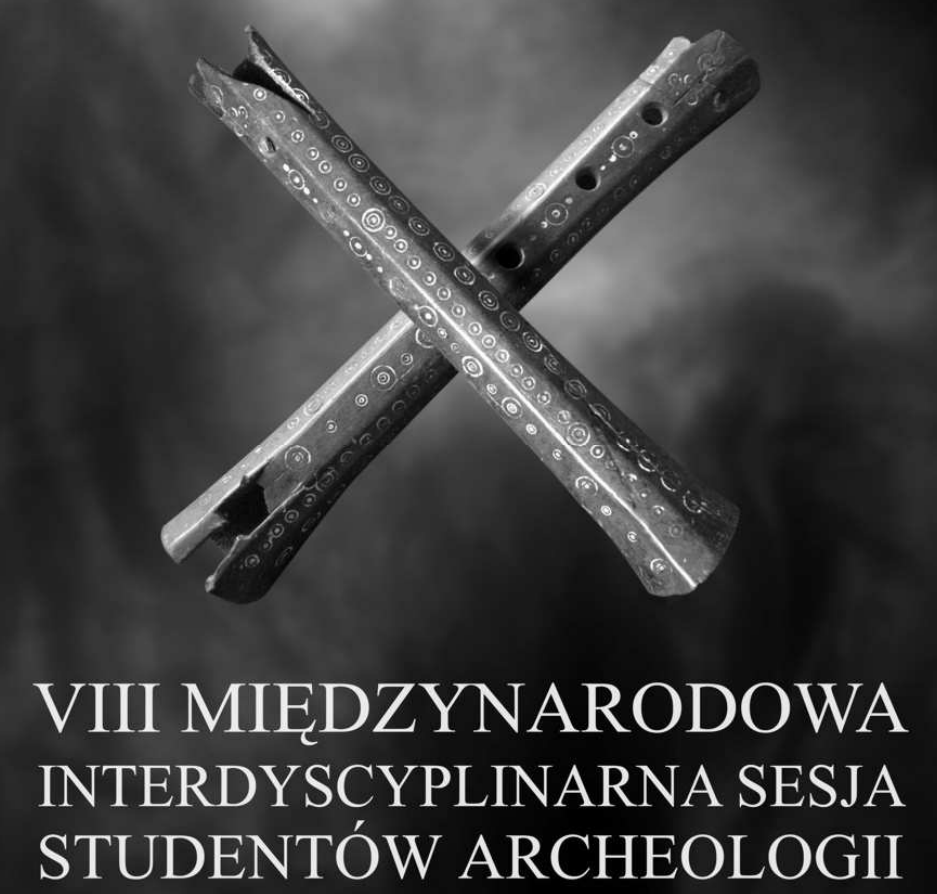

PUSZCZYKOWO 18-20 GRUDNIA 2006

Koło Naukowe Studentów Archeologii przy Instytucie Prahistorii UAM w Poznaniu

i tańca, w różnych kontekstach kulturowych. Próbowali oni zdefiniować omawiane zjawiska oraz zastanowić się, w jaki sposób archeolodzy, korzystając z dorobku innych dziedzin, mogą zabrać głos w dyskursie na tematy z pozoru odległe ich zainteresowaniom.

$\mathrm{W}$ trakcie dwóch ostatnich dni konferencji jej uczestnicy mieli również okazję wzięcia udziału w trzech symultanicznie odbywających się zajęciach warsztatowych. Ta nietypowa forma dyskusji stała się już wizytówką owych sesji i miała na celu bliższe zapoznanie się studentów, a co za tym idzie, również bardziej aktywną i swobodną wymianę poglądów. Uczestnicy konferencji zostali podzieleni na trzy zespoły, dzięki czemu mogli brać udział we wszystkich trzech zajęciach. Autorami warsztatów pt. „Mu- 
zyczna przestrzeń rytuału” byli studenci archeologii: Monika Włodarczak, Paweł Polkowski, Łukasz Banaszek i Piotr Porzycki. Poprzez teatralną próbę „odtworzenia” dawnych obrzędów oraz towarzyszącą im muzykę wykonywaną na żywo przez prowadzących, zaproponowali oni dialog na temat muzyki, śpiewów i tańców wykorzystywanych w trakcie różnego rodzaju rytuałów oraz postępowaniu archeologa w celu ,rekonstrukcji” tych czynności. Przedstawiciele Katedry Muzykologii: Małgorzata Wójciak, Ewelina Grygier oraz Łukasz Smoluch w swoich zajęciach o nazwie „Muzyka mniej znana, czyli o co ten cały harmider" zapoznali uczestników z różnymi, przedziwnymi niekiedy, sposobami wykonywania i znaczeniem rozmaitych dźwięków i tańców. Trzecie warsztaty zostały zatytułowane „Piosenka jest dobra na wszystko. O kabarecie, muzyce i nie tylko...”. Poprowadzili je: studentka psychologii i archeologii Kinga Vorbrich oraz przedstawiciel polonistyki Marcin Jauksz. Poprzez multimedialną prezentację zaproponowali oni dyskusję na temat kabaretu, muzyki i śpiewu jako czynników sprzyjających niwelowaniu stresu i wprowadzających w stan relaksu.

Celem konferencji było stworzenie interdyscyplinarnego dialogu między przedstawicielami różnych kierunków humanistycznych. Dzięki temu studenci z KNSA, proponując tak odważny i rzadko poruszany w polskiej archeologii temat, wyszli poza granice własnej dyscypliny i zaproponowali szersze spojrzenie na zjawiska dźwięków i muzyki w różnych sferach egzystencji człowieka (w tym również w przeszłości).

Maksymilian Frąckowiak

Instytut Prahistorii, Uniwersytet im. Adama Mickiewicza ul. Św. Marcin 78, 61-809 Poznań, Poland 